\title{
Combating international crimes in Iraqi legislation
}

\author{
Fadil Radi Mohamed ${ }^{1}$, Zaman Sahib Majdi², Mohammed Hamzah Owaid ${ }^{3}$, Zainab Kazem Talib ${ }^{4}$ \\ ${ }^{1}$ Lecturer,College of Biotechnology, Al-Qasim Green University, Iraq, ${ }^{2}$ Assist. Lecturer, Factuly of law, University \\ of Kufa, Iraq, ${ }^{3}$ Assist. Lecturer, University of Babylon, Iraq, ${ }^{4}$ Bachelor's, Al-Qasim Green University, Iraq
}

\begin{abstract}
The terrorist financing activities are considered one of the most important threats that facing the security and safety of people of society in all its forms, as their danger increases by adopting a pattern of transnational organized crime. There is no longer planning, managing and implementing them is done within the territory of one country, but its lines are woven across multiple countries to conduct them in the targeted country with the crime. Iraq comes in the forefront of countries that suffered from terrorism and the violent crimes,in order to strike stability in it, also to sow discord and sectarian fighting for this, the Iraqi state must confront the terrorism in general, as well as the terrorist financing activities in particular, reducing its seriousness and punish the perpetrators, so, the Anti-Terrorism Law No. 13 of 2005, and the Anti-Money Laundering and Terrorist Financing Law No. 39 of 2015, was issued, as it was issued in implementation of Article 22 of the Money Laundering Law that was mentioned previously,this leads to the question about the adequacy of these legal texts to address the crime of financing terrorism, whether the Iraqi legislator succeeded in putting in place the necessary mechanisms with the appropriate part to prevent these funds for reaching to the hands of terrorist organizations.
\end{abstract}

Keywords: Terrorism, penalties, Anti-Terrorism.

\section{Introduction}

Criminal legislation did not agree on a unified concept of terrorism, as this is normal in light of the variation in their perception of terrorism ${ }^{(1)}$ because it is in what is considered a terrorist act in the eyes of a specific country or a specific community may not be considered so in the view of another country or society (2) then by referring to the Iraqi Penal Code No. 111 of 1969, it did not include a definition of terrorism, but it indicated in item (a) of Article (21) of it that the terrorist crime is not considered a political crime without specifying its concept, as this is a legislative deficiency in it, where it referred to a term without defining its concept.As for the Iraqi Anti-Terrorism Law No. 13 of 2005, terrorism was defined in its first article as: (Every criminal act by an individual or an organized group that has targeted an official or unofficial individual or groups or institutions or has caused damage to public or private property in order to disturb the security situation, stability and national unity or introduce terror or fear among people, creating chaos to achieve terrorist goals) in this way, the Iraqi legislator has followed the direction that was limited to defining terrorism without mentioning terrorist crimes, as some may see that what distinguished the definition that the legislator which he mentioned in the anti-terrorism law is that he limited terrorism to the acts that were criminalized by the law as the description was not detailed, that this is one of the advantages of the text that prevents the authority from arbitrarily using its authority in the fight against terrorism ${ }^{(3)}$, while we can find others criticizing this definition in several ways, on the one hand, it was limited to the terror of individuals and groups, that the state terrorism has not been shown despite the gravity of the threat which is posed by terrorism of the state, on the other hand, others see that what the Iraqi legislator did not represent a definition of terrorism, but a description of the act of terrorism that it is counting and formulating a group of criminal acts, that which must be give a direct definition of the term terrorism, inaddition, its formulation according to which the definition was established was weak, as the definition is broad, as well as the phrase (achieving terrorist purposes) contained in the definition came vague, as the legislator did not show what these goals were, nor did he explain the criteria for determining them ${ }^{(4)}$,As for the 
term terrorism financing, it has been dealt with by economists more than that dealt with by legislators, as the economists have defined it as (searching for sources through which money can be spent to spend it on implementing or conducting a plan) ${ }^{(5)}$, also others define it as (taking the necessary measures to obtain funds from their appropriate sources at the appropriate time and on satisfactory terms) ${ }^{(6)}$,as for the jurists of the law, they have defined the financing of terrorism as (providing or collecting, under any name, money or related services for the purpose of using it, or that he knows you will use all or part in a work that provides benefit to any individual or collective terrorist project and whether or not the result is achieved) ${ }^{(7)}$ It is also it was defined as (financial support in various forms which is provided to individuals and organizations that support terrorism or who are planning terrorist operations, as the transfer may come from legitimate sources such as charities, for example, with or without intent or other illegal sources, for example, the trade of damaged goods and drugs) ${ }^{(8)}$, while others went on to define it as (financial support or presenting financial support in any form for terrorism, or for those who encourage or develop its plans, or participate in or assist in it, or those who personally undertake terrorist operations) ${ }^{(9)}$. In light of these definitions that are provided for the financing of terrorism, it can be said that the financing of terrorism is every act through which, whether directly or indirectly, collecting, or providing money or whatever is equivalent to it to a terrorist group or terrorist person, or the intention of the perpetrator is to use it for terrorist purposes. The sources of financing terrorism have developed in Iraq after the terrorists which occupied several cities in the northern and the western of Iraq from traditional sources of financing, which are represented by rented murder, kidnapping, robbery, armed robbery and other terrorist acts to the more organized and more self-financing sources of influence and larger, traditional internal funding sources no longer meet the aspirations of terrorist groups in Iraq, this is because these groups seek to expand their areas of influence to include new regions to disperse the international efforts to combat it on one hand, establishing terrorist bases of influence in areas that are allowed to move across international borders to facilitate the movement of their trade, whether from smuggling crude oil, antiquities or other, in addition for expanding its revenues from customs duties, whether through transit fees for foreign trade between Iraq and a number of neighboring countries, or by paying the fees to their terrorist groups to facilitate the transportation of crude oil to the sources of maritime transport through pipelines that pass in the controlled by the territories. Among the most important sources of self-financing for the terrorist groups in Iraq are the revenues from oil exports which derived from the sale of crude oil, smuggling it from dominated fields and trafficking in evil, as well as smuggling Iraqi antiquities ${ }^{(10)}$. The sources of financing terrorist operations in Iraq have varied in various forms and in various styles, with the aim of continuing the sources of financing to the maximum extent possible. So the terrorists are already developing new measures and plans to finance it, that the method that succeed in combating it become, as soon as they are successful, outdated method, as terrorism like malaria is changing continually and constantly, among the most important sources of its financing are money laundering, international financing, foreign aid, external financial support, external financial transfer, and others in the absence of financial control from and to Iraq, as most terrorist operations are funded from abroadwhich is from suspicious sources, however, a statement issued by the White House stated that 29 of the largest groups that deal in drugs that were classified by the US Department of Justice in 2010, as its number was 63, it had an association with terrorist organizations, which indicates that administrative corruption with the loss of citizenship for the motherland will cause harm not only to the country itself, but will also harm other countries, so how it could be going on if terrorism, administrative corruption, loss of citizenship, national identity and political sectarian tension in the same country as in Iraq? Also government agencies may participate, with or without intent, in financing terrorist operations. Often times, commercial deals are conducted to finance goods such as foodstuffs, equipment, devices, etc. from outside Iraq without external financial transfer for some Iraqi merchants, then those commercial deals are disposed of and sold on the local market, therefore the financing of terrorist operations is carried out from those suspicious deals ${ }^{(11)}$.When the legislator actually criminalizes something, he sets a penalty commensurate with the gravity of this act, so the punishment is a penalty determined by the law which is signed by the judge for an act that is considered a crime in the law,so the punishment, then, must be prescribed by a text in the law and must be signed within the limits of what the law says according to the principle (no crime or punishment except by text)), accordingly, we will deal in this pillar with the penalties or punishments which are prescribed for the crime of financing the original, dependent and 
complementary terrorism. The original penalties for the crime of financing terrorism are life imprisonment, as this is stipulated in Article (37) of the Money Laundering and Terrorist Financing Law which is conducted, while the Anti-Terrorism Law went to criminalize the financing of terrorism as a form of criminal behavior in the crime of inciting of a sectarian strife in the fourth item of the second article, whereas the financier's punishment was specified in the second item of the fourth article as it came in it: (... the financier and anyone who enabled the terrorists to carry out the crimes that were mentioned in this law shall be punished with the punishment of the original perpetrator), meaning that this article considers him a partner in the terrorist crime, as the financier shall be punished with the punishment stated in the AntiMoney Laundering Law, as the funded terrorist crime did not take place, as it is an original actor in the crime of financing terrorism, that is, the text of Article (1) item (10) of the Anti-Money Laundering Law applies to it. But if the result is achieved, that is, if the funded terrorist crime occurred, the financier shall be punished with the punishment stipulated in the second paragraph of Article 4 of the Anti-Terrorism Law as a partner in the terrorist crime,therefore, we can sum up the financier's penalty in general with the following penalties:

1. The death penalty: The legislator considered the death penalty to be the appropriate punishment against the terrorists, since the gravity of the danger and the gravity of the damage that results from these crimes are what prompted the legislator to decide that punishment, as it is the best deterrent for such criminals, so the legislator has done well when he stipulated that punishment despite the voices of those opposing it.

2. As we see if the Iraqi legislator added to the death penalty the maximum by taking measures to resolve terrorist cases and counting them as urgent cases, provided that there are different courts to consider their cases and fast in issuing rulings on them, so as not to delay the resolution of their cases and be subject to external and internal interference from them, then the innocent right is lost because justice has not been achieved, as there was no deterrent and decisive later on for the criminals who did not apply on them the death penalty.

The subordinate penalties, according to Article (25) of the Iraqi Penal Code are (that inflicts on the convicted by the rule of law without the need to stipulate it in the ruling) Article (20) of the Iraqi Penal Code stipulates that: (Every judgement of the death penalty entails the rule of law from the day it was issued until the time of the execution of the judgement, depriving the convict of the rights and benefits that were stipulated)

In the two preceding articles, there is invalidity of every act of management and administration that is issued during the aforementioned period, except of the will and cessation, the Personal Status Court or the Personal Material Court is appointed according to the cases which are based on the request of the public prosecution or any person of valuable interest to the convict), as the deprivation that which mentioned in this article includes the rights which were mentioned in Article (21) penalties and they are as follows:

1. Jobs and services he undertakes

2. To be a voter or elected in the representative councils

3. To be a member of the administrative or municipal councils or one of the companies or was a director

4. To be a trustee or agent

5. He must be the owner, publisher or president of a newspaper

As for the material precautionary measures in the crime of financing terrorism, the Iraqi legislator did not define the material precautionary measures, but rather he explained their types and provided for material precautionary measures that could be applied to the convictby committing the crime of financing terrorism, the measures that are confiscation with the removal or dissolution of the legal entity.

Recommendations: After we have completed our humble study, we can recommend a number of points, as it would be desirable if the competent authorities and the legislative bodies took them, as the most important of them are: The necessity of activating the national supervisory to monitor the sources of financing terrorism, especially in relation to money laundering, human smuggling and sale in the slave market. Issuing deterrent penalties for media promoters of terrorist groups and refraining from granting them legitimate descriptions. Respecting human rights and rejecting violence in all of its forms. Prosecuting cross-border crimes through cooperation and agreement with other countries in the judicial areas and facilitating, extraditing and transferring the accused to bring them to trial. The necessity for national laws in their formulation to combat terrorism and the financing of its sources to take into account all possible aspects of 
them with the existence of prior studies on the nature of societies and their national also ethnic configurations, so that they do not lead to provoking counteractions from the purpose of their legislation, so that they are far from applying them to human rights violations.

Financial Disclosure: There is no financial disclosure.

Conflict of Interest: None to declare.

Ethical Clearance: All experimental protocols were approved under the College of Biotechnology and all experiments were carried out in accordance with approved guidelines.

\section{References}

1. Muhammad MM. Terrorism and Maritime Piracy, Naif University for Security Sciences, Riyadh, 2006; 91.

2. Ahmad F. The Future of Terrorism in this Century, Naif University for Security Sciences, Riyadh. 2006; 15.

3. Sam RM, Definition of Terrorist Crime. 2014.

4. Khaled M. Criminal Policy in the Anti-Terror Law, A Comparative Study, Master Thesis, University of Babylon, College of Law, 2010; 3.

5. Ziad SR. Fundamentals of Financial Analysis, 1st edition, Dar Safaa, Amman, without a year of printing. 2000; 49.

6. Mohamed A. Introduction to Development and Planning, Arab Renaissance House, Cairo.1982; 49.

7. Fadel SA. The Crime of Terrorism Funded by
Money Laundering, Master Thesis, University of Al-Nahrain, College of Law, Year 2012; 12.

8. Muhammad A. Drying the Sources of Terrorist Financing, 1st edition, Naif University for Security Sciences, Riyadh, 2001; 22.

9. Mai M. The Crime of Financing Terrorism in Syrian Legislation, Damascus University Journal for Economic and Legal Sciences, first issue, year $2012 ; 212$.

10. The First International Scientific Conference on Terrorism (Towards a Security Society Free from Terrorism on February 18-19, 2017, Research on Sources of Financing Terrorism in Iraq and its Treatments, Researcher name Haitham Abdullah Al-Ghazawi, p. 6, published on the website http:// un.uobasrah. edu.iq/6580.

11. Ali HK, Sultan A. General Principles in the Penal Code, Obelisk Press, Kuwait, 1982; 431.

12. Mohamed AW. Fundamentals of Criminality and Punishment, First Edition, Wael House, Amman, $2002 ; 332$.

13. Khaled MA. Criminal Policy in Iraqi AntiTerrorism Law, A Comparative Study, Master Thesis, University of Babylon, College of Law. 2010.

14. Fadil SA. The Crime of Terrorism Funded by Money Laundering, MA Thesis, Al-Nahrain University, College of Law, 2012.

15. Haitham AA. Sources of Financing Terrorism in Iraq and its Treatments. 2017.

16. Salem RA. Definition of the terrorist crime, on the website http://annabaa.org.2014. 